\title{
The Predictability and profitability of Trading Range Break-out Trading Rules: Evidence from Pakistan Stock Exchange
}

\author{
Syed Arshad Ali Shah \\ Lecturer, Department of Management Science \\ Bacha Khan University Charsadda \\ arshad@bkuc.edu.pk \\ Dr.Anwarul Mujahid Shah \\ Lecturer, Department of Sociology, Political Science and Education \\ Bacha Khan University Charsadda \\ Dr.Saiful Mujahid shah \\ Lecturer, Department of Economics, NUML Islamabad
}

\begin{abstract}
The efficient market hypothesis has been one of themost extensively researched topics in the academic literature for decades. An implication ofweak form of efficiency is that the technical trading rules will not produce abnormal returns. The purpose of this research is to analyze findings of application of trading range breakout test on daily closing share prices of 100 companies listed on a Pakistan Stock Exchange over ten years from 2006 to 2015, thus examining its efficiency at the weak form. The results show strong support for trading range break-out rules having both predictability and profitability for PSX. It refers that the returns from these rules are not same as investors earn from a naïve buy and hold strategy. The uses of the trading range break-out rules produce abnormal returns to investors and hence nullify the weak form of efficiency on PSX.
\end{abstract}

Keywords: Trading Range Break-out rules; Pakistan Stock Exchange; Efficient Market Hypothesis; Weak form of Efficiency; Nä̈ve Buy and Hold Strategy

\section{Introduction}

Technical Trading Rules (TTRs) are a technique applied by traders to decide at what time to buy and sell shares. The TTRs depend on the analysis of the historical stock prices, stock returns and trade volume of stock to determine price tendencies and future movements. The TTRs represents a contest the efficient market hypothesis $(\mathrm{EMH})$, specifically in its weak form of efficiency. The weak form of efficient marketcontends that stockholders should not be able to produce positive risk-adjusted profits from observing past price data, as prices already reflect all available historical information (Fama, 1970). As per the EMH, the TTRs are ultimately useless. As technical strategy is applied only to the past data, on the basis of such data it is not conceivable to attain abnormal returns. If stockholders could earn abnormal returns from applying the TTRs , it's may be the sign that these markets is not efficient 
(Tharavanij, Siraprapasiri, \& Rajchamaha, 2015). The purposeof researchis twofold. We examine the predictability and profitability of the TTRs i.e., Trading Range Break-out Rules (TRB) in the firm-level share price data on the Pakistan Stock Exchange (PSX) and can outperform the buy and hold strategy.

\section{Review of Literature}

Much of the early research literature on the finance tries to study the predictability of the TTRs and the results of all these studies were supported the EMH (Jensen \& Benington, 1970; Van Horn \& Parker, 1967; Fama \& Blume, 1966; Fama, 1970; Alexander, 1964; Granger \& Morgenstern, 1963; Osborne, 1962; Larson, 1960; Kendall \& Hill, 1953), establishedthat TTRs are not useful in forecasting powerin share prices and not outperform naïve the buy and hold planand the investors can not earn excess return. Before the90s, much of the financialexperts whispered that TTRs is uselessfor return predictability. However, seminal research works on TTRs by (Lakonishok LeBaron, 1992; Yu, Nartea, Gan, \& Yao, 2013; Metghalchia, Marcucci, \& Chang, 2012; Hudson, Dempsey, \& Keasey, 1996; Brock, Lento \& Gradojevic, 2007; Ni, Lee, \& Liao, 2013), show that TTRs have forecasting ability.

Ahmad, Beck and Goldreyer (2000) studied the predictive ability of TTRs in 03 highly unpredictable and weakening Asian equity markets (Taiwan, Thailand and Philippines). They used daily returns of the three stock exchange ${ }^{1}$ from February 1994 to March 1999 and establish that SMA techniques can beat a buy and hold plan and also suggested that these markets have forecasting ability although with the existence of trade costs.

To exam the performance of the rules on nine most active Asian financial market indices for the time interval 1988 to 2003. The daily closing price index was used. The findings presented the rules had strongly forecast power in Twain,Indonesia, China, Korea, Hong Kong, Malaysia, Thailand and Singapore and financial markets (Ming-Ming and Siok-Hwa, 2006).

The study of Almujamed, Fifield, and Power (2108) employed the technical trading rules for the forty two firms of Kuwait Stock Exchange (KSE) and found that the filter rules had predictability power of stock prices in KSE. Metghalchi, Hajilee and Hayes (2018), studied the forecasting ability and profitability of the technical trading rules on Bulgarian Stock Index since 2003 to 2018. The results strongly supported that the rules have the ability of forecasting. The study also confirms that these rules beat the buy and hold strategy in the Bulgarian stock index in the study period.

This study changes for the earlier studies on conductingvarious financial markets, from the above studies use index data for analysis. The uniqueness of the study is the use of daily share prices of 100 firms listed on PSX over the period 2006 to 2015 using trading range break-out rules.

\section{Methodology \\ Data}

This study applies firm level daily closing prices of shares of 100 firms listed the PSX. These are companies with the highest market capitalization on the first

\footnotetext{
${ }^{1}$ Bangkok S.E.T through the Taipa Weighted Price Index, and Manila Composite Index
} 
trading on 2006, from the January 2, 2006 to December 31, 2015. The returns for each firm are calculated on the below formula:

$\mathrm{P}_{\mathrm{it}}=\mathrm{Ln}\left[\left(\mathrm{K}_{\mathrm{it}} / \mathrm{K}_{\mathrm{it}-1}\right)\right]$

Where

$\mathrm{P}_{\mathrm{it}}$ isthe return on a share $i$ for the day $t ; \mathrm{K}_{\mathrm{it}}$ is the share price at time $\mathrm{t}$,

$\mathrm{K}_{\mathrm{it}-1}$ represents the share price at time $\mathrm{t}-1$, ; Ln denotes the natural logarithm.

TRB is also known as support and resistance usually used within trading rules. TRB rules contain comparing the existing price to the local (recent) minimum and maximum. A buy signal is produced under the TRB, when the existing price is above the resistance level by at least a pre-defined percentage of band. For TRB, the resistance level is defined as "the level of local maximum price" (Yu et al., 2013). Technicians have faith in that many traders are agreeable to sell at peak. Under the TRB, a sell signal is produced when the existing price falls below the support level by at least a pre-defined percentage of bands. The support level is defined as "the level of local minimum price" (Brock et al., 1992). The basic logic is that the current price has difficulties pierces the support level for the reason that traders agreeable to buy at the recent support price. Although, if the current price goes below the recent minimum price, the price is probable to sink. Technicians suggested buying when the price exceeds its previous peak and selling when the price drifts downward its previous trough. For the sake of this study, similar TRB rules were adopted by Brock et al., (1992), where local maximum (minimum) prices are defined as those based on the prior 50,150, and 200 days respectively. Moreover, the trading rang break-out rules is employed from 0 and $1 \%$ band, making for total of six TRB rules, to wit: $(1,50,0)$, $(1,50, .01),(1,150,0),(1,150, .01),(1,200,0)$ and $(1,200, .01)$ combinations and then calculate each TRB rules using fixed trading horizons of 10 days. Generally, these rules are recognized as (short, long, band); where short is the span of time to covered in the short run and long is span of time to covered in the long run, and band is the percentage difference that is required to produce signals. For example $(1,150,1) 1$ denotes short period, 150 denotes the long run period and 1 represent the size of bandwidth in percentage.

The following formulas used for the generating of buy and sell signals.

$\mathrm{K}_{\mathrm{t}}>(1+\mathrm{Y}) \max \left(\mathrm{K}_{\left.\mathrm{t}-1, \ldots, \mathrm{K}_{\mathrm{t}-\mathrm{m}}\right)=\text { Buy }}\right.$

And

$\mathrm{K}_{\mathrm{t}}<(1+\mathrm{Y}) \min \left(\mathrm{K}_{\left.\mathrm{t}-1, \ldots, \mathrm{K}_{\mathrm{t}-\mathrm{m}}\right)=\text { Sell }}\right.$

Source: Cheung, Lam, \& Yeung (2011)

Where: $\mathrm{K}_{\mathrm{t}}$ is the stock price at time $\mathrm{t}$; $\mathrm{m}$ is the time period $(50,150$, and 200 days respectively)

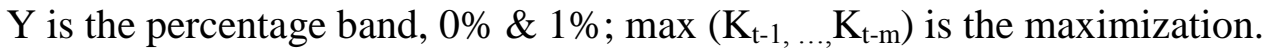

\section{Results and Discussions}

Table 1 refers the summary statistics of the ten years for ten days returns. Table 1 shows the results of ten day return, which is used for comparison the result of TRB 
method. Ten day mean return of 0 . percent is reported by sample firms. The standard deviation of returns resulted to be percent as per our analysis.

Table 1 : Basic statistics of daily return of PSX.

\begin{tabular}{|l|l|}
\hline (Average 10 days) \\
\hline Mean & St.Dev \\
\hline 0.001054 & 0.011316 \\
\hline
\end{tabular}

The Table shows the descriptive statistics of the PSX over the period of 10 years (2006-2015).The mean presents the equally weighted average of the daily and ten days observations over the 10- years. Std.Dev, present the standard deviation of the daily and ten day returns. The number marked with $*$ is significant at $1 \%$ level.

Trading Range Brea -Out Rules.

The TRB rules are examined within imposition of 10-day post signal holding period return. Afterwards, the same returns are compared to the non-overlapping ten-day unconditional returns for the particular test time frame. 
Table 2

\begin{tabular}{|c|c|c|c|c|c|c|c|c|}
\hline \multicolumn{9}{|c|}{ Result of TRB rules of PSX } \\
\hline PERIOD & Rules & N.BUYS & N.SELLS & $\begin{array}{l}\text { BUY } \\
\text { Mean }\end{array}$ & $\begin{array}{l}\text { SELL } \\
\text { Mean }\end{array}$ & Buy $>0$ & Sell $>0$ & Buy -Sell \\
\hline 2006-2015 & $(1,50,0)$ & 1422 & 1421 & $\begin{array}{l}0.006528 \\
(5.6978)\end{array}$ & $\begin{array}{l}-0.00874 \\
(- \\
7.6105)\end{array}$ & 0.028927 & 0.021018 & $\begin{array}{l}\mathbf{0 . 0 1 5 2 6 8} \\
(9.436287)\end{array}$ \\
\hline 2006-2015 & $(1,50, .01)$ & 1485 & 1484 & $\begin{array}{l}0.007591 \\
(6.7696)\end{array}$ & $\begin{array}{l}-0.00622 \\
(- \\
5.5319)\end{array}$ & 0.030096 & 0.020636 & $\begin{array}{l}\mathbf{0 . 0 1 3 8 1 1} \\
(8.723138)\end{array}$ \\
\hline 2006-2015 & $(1,150,0)$ & 447 & 446 & $\begin{array}{l}0.01014 \\
(2.5366)\end{array}$ & $\begin{array}{l}-0.0225 \\
(- \\
5.6165)\end{array}$ & 0.036809 & 0.023356 & $\begin{array}{l}\mathbf{0 . 0 3 2 6 4 0} \\
(5.771356)\end{array}$ \\
\hline 2006-2015 & $(1,150, .01)$ & 466 & 465 & $\begin{array}{l}0.01059 \\
(5.2940)\end{array}$ & $\begin{array}{l}-0.01855 \\
(- \\
9.2518)\end{array}$ & 0.038692 & 0.022719 & $\begin{array}{l}\mathbf{0 . 0 2 9 1 4 0} \\
(10.296136)\end{array}$ \\
\hline 2006-2015 & $(1,200,0)$ & 341 & 340 & $\begin{array}{l}0.009921 \\
(2.1686)\end{array}$ & $\begin{array}{l}-0.02845 \\
(- \\
6.2038)\end{array}$ & 0.039012 & 0.023194 & $\begin{array}{l}\mathbf{0 . 0 3 8 3 7 1} \\
(5.926199)\end{array}$ \\
\hline 2006-2015 & $(1,200, .01)$ & 355 & 354 & $\begin{array}{l}0.01026 \\
(4.4817)\end{array}$ & $\begin{array}{l}-0.02434 \\
(- \\
10.607)\end{array}$ & 0.040330 & 0.023289 & $\begin{array}{l}\mathbf{0 . 0 3 4 6 0 0} \\
(10.679764)\end{array}$ \\
\hline AVERAGE & & & & 0.0091717 & -0.01813 & & & 0.027305 \\
\hline
\end{tabular}

The Table 2 contains the findings of six TRB rules for the PSX; these rules are tested on the time period 2006-2015, with 0 and $1 \%$ band.

Column II of the Table 2 refers to the rules, whereas columns III and IV show thedays of buy and sell signals for the various strategies respectively. The column V reports the daily mean of buy returns while the column VI represents the daily mean of sell returns. Similarly the both columns i.e., V and VI show the value of $t$-statistic, which examine the quality of respective returns having unconditional mean daily returns.

Further, columns VII and VIII show the figure of the fraction of the buy and sell respectively. The overall figure of the buy mean returns is positive while the mean average of return is 0.91 percent, while the overall figure of the sell mean returns is negative, the mean average of return is -0.18 percent. The null hypothesis according to the return is equal ten-day unconditional returns is rejected for both buy and sell of all six tests, for the said purpose the two tailed test are applied at $1 \%$ significance level, almost which closed as already reported by Hudson et al. (1996) and Brock et al. (1992).

The findings are highly statistically significant for both returns. The fraction figure for buys higher than zero, similarly for sells its value also higher than zero. This result is obtained from the data is similar to Hudson et al. (1996). The null hypothesis of 
equality is rejected because t-test is highly noteworthy. The buy-sell mean is positive and the average 0.27 percent (see Table 2). At the $1 \%$ standard level, the null hypothesis can be rejected for all the six rules as the difference is equal to zero. Adding $1 \%$ band to the rules increase the buy-sell difference. These overall findings are similar to (Corbet et al., 2019; Metghalchi et al., 2018; Hudson et al., 1996; Brock et al., 1992).

\section{Conclusion}

This paper studies the predictability and profitability of the TTRs (applying the trading Range Break-out rules) and its implication for examining the weak form of efficiency on the Pakistan financial market. The findings of the TRB rules show that stock returns in PSX are predictable, the numbers of days of both (buy and sell) signals are similar. The buy mean returns of all rules are positive and rejected that the null hypothesis of the buy mean returns is same to unconditional returns; the same results are for sell mean returns. The results also recommend that The PSX is not a weak form of efficient. Finally, TRB rules prove that the traders can earn the excess profits on this market using technical trading rules.

\section{References}

Ahmed, P., Beck, K., \& Goldreyer, E. (2000). Can moving average technical trading strategies help in volatile and declining markets? A study of some emerging Asian markets. Managerial Finance, 26(6), 49-62.

Alexander, S. S. (1964). Price Movements in Speculative Markets--Trends or Random Walks,

Almujamed, H. I., Fifield, S. G., \& Power, D. M. (2018). An investigation of the weak form

of the efficient markets hypothesis for the Kuwait stock exchange. Journal of EmergingMarketFinance, 17(1), 1-28.

Brock, W., Lakonishok, J., \& LeBaron, B. (1992). Simple technical trading rules and thestochastic properties of stock returns. The Journal of finance, 47(5), 1731-1764.

Cheung, W., Lam, K. S., \& Yeung, H. (2011).Intertemporal profitability and the stability of technical analysis: evidences from the Hong Kong stock exchange. Applied Economics, 43(15), 1945-1963.

Corbet, S., Eraslan, V., Lucey, B., \&Sensoy, A. (2019).The effectiveness of technical trading rules in cryptocurrency markets. Finance Research Letters, 31, 32-37.

Fama, E.F. (1970). Efficient Capital Markets: A Review of Theory and Empirical Work. The Journal of Finance, 25, 2, 383-417.

Fama, E. \&Blume, M. (1966), "Filter rules and stock market trading", Journal of Business, Vol. 39, pp. 226-41.

Granger, C., \& Morgenstern. O. (1963). Spectral Analysis of New York Stock Market Prices. Kyklos 16 (February): 1-27.

Hudson, R., Dempsey, M., \& Keasey, K. (1996). A note on the weak form efficiency of

capital markets: The application of simple technical trading rules to UK stock prices-

1935 to 1994. Journal of Banking and Finance, 20(6), 1121-1132. 
Jensen, M. C., \& Benington, G. A. (1970). Random walks and technical theories: Some additional evidence. The Journal of Finance, 25(2), 469-482.

Kendall, M. G., \& Hill, A. B. (1953). The Analysis of Economic Time-Series-Part I: Prices. Journal of the Royal Statistical Society Series A 116 (1): 11-34.

Lento, C., \& Gradojevic, N. (2007). The profitability of technical trading rules: A combined signal approach. Journal of Applied Business Research, 23(1), 13.

Metghalchi, M., Marcucci, J., \& Chang, Y. H. (2012). Are moving average trading rules profitable? Evidence from the European stock markets. Applied Economics, 44(12), 1539-1559.

Metghalchi, M., Hajilee, M., \& Hayes, L. A. (2018). Return Predictability and Market Efficiency: Evidence from the Bulgarian Stock Market. Eastern European Economics, 1-18.

Ming-Ming, L., \& Siok-Hwa, L. (2006).The profitability of the simple moving averages and trading range breakout in the Asian stock markets. Journal of Asian Economics, 17(1), 144-170.

Ni, Y. S., Lee, J. T., \& Liao, Y. C. (2013). Do variable length moving average trading rules matter during a financial crisis period? Applied Economics Letters, 20(2), $135-141$.

Osborne, M. (1962). Periodic Structure in the Brownian Motion of Stock Prices. Operations Research 10 (3): 345-379.

Tharavanij, P., Siraprapasiri, V., \& Rajchamaha, K. (2015). Performance of technical trading rules: evidence from Southeast Asian stock markets. Springer Plus, 4(1), 552.

Van Horne, J. C., \& Parker, G. G. (1967). The random-walk theory: an empirical test. Financial Analysts Journal, 23(6), 87-92.

Yu, H., Nartea, G. V., Gan, C., \& Yao, L. J. (2013). Predictive ability and profitability of simple technical trading rules: Recent evidence from Southeast Asian stock markets. International Review of Economics \& Finance, 25, 356-371. 